\title{
ARCHITEKTONICZNE ŚRODKI TWORZENIA GRANIC SPOŁECZNYCH WOKÓŁ IMIGRANTÓW W MIASTACH
}

\begin{abstract}
Amiri Oskar, Architektoniczne środki tworzenia granic społecznych wokót imigrantów $w$ miastach [Architectural means of creating social boundaries around immigrants in the cities] edited by J. Kubera, Ł. Skoczylas - „Człowiek i Społeczeństwo”, vol. XXXVII, Poznań 2014, pp. 125-135, Adam Mickiewicz University Press. ISBN 978-83-232-2764-9. ISSN 0239-3271.

Immigrants in the cities sometimes use architectural means to mark their presence, as well as a separate identity. These activities are often superficial, aesthetic, due to the asymmetry in the means of power in the urban space. On the other side there are the planners, having other plans towards enclaves, and the possibility to introduce them. Urban development is therefore a conflict of interest of different groups, and the result illustrates this dispute. It is a dispute which has a different outcome every time, just as the cultures coexisting in the cities are different, with different needs, identities and history.
\end{abstract}

Oskar Amiri, Politechnika Poznańska, Wydział Architektury, ul. Nieszawska 13c, 61-021 Poznań, Poland.

\section{WSTĘP}

Współcześnie już ponad połowa populacji Ziemi żyje w miastach, przy czym tendencja pozostaje wzrostowa. Zwiększa się także mobilność społeczna, co przy otwarciu granic państw z niektórych regionów skutkuje wzrastającą liczbą imigrantów w ośrodkach miejskich. Wzory osiedleńcze nie mają jednolitego charakteru, są też różnie wartościowane. Unikając oceny zjawiska migracji do miast, chciałbym skupić się na jego przestrzennym aspekcie. $W$ artykule podjęto próbę omówienia środków architektonicznych, poprzez które stworzono imigrantom przestrzenne enklawy w miastach. Jako materiał badawczy wybrano kilka ośrodków miejskich posiadających rozpoznane i nazwane enklawy, głównie o charakterze etnicznym. Występujące rozwiązania analizowano w szerokim zakresie - od decyzji urbanistycznych po detal architektoniczny. Nie bez znaczenia okazało się także 
przyjrzenie się definicjom takich pojęć, jak: imigrant, enklawa, getto, swój i obcy, których rozumienie częściowo determinuje problem i jego postrzeganie.

\section{PRZYCZYNY MIGRACJI I TWORZENIA ENKLAW}

Przyczyn migracji jest wiele: od rodzinnej, religijnej, narodowościowej, politycznej aż po zarobkową (Jagielski 1974). Imigranci w dużych miastach mogą $\mathrm{w}$ pewnym stopniu kojarzyć się $\mathrm{z}$ mającymi pracę bądź szukającymi jej osobami spoza kraju, czasem nawet $\mathrm{z}$ innego kręgu kulturowego. Powodem takiego stanu rzeczy mogą być uwypuklające ich obecność różnice, chociażby językowe. Prawdopodobnie osobom bliższym językowo i kulturowo łatwiej jest się zasymilować z lokalną ludnością, a zatem wtopić się w społeczeństwo (Grzymała-Kazłowska, Piekut 2007). Na przebieg integracji może też mieć wpływ różnica w kolektywności stykających się kultur (Hall 1976). Osoby z zagranicy nie są jedyną grupą migrującą do miast. Stanowią one, oprócz ludzi z prowincji, innych miast czy osiedlających się w pobliżu dużych ośrodków ludzi zamożnych, jedynie część wszystkich migrujących być może najłatwiej rozpoznawalną. Każda ze zmiennych kulturowych, prawnych czy środowiskowych będzie miała wpływ na wzory osiedleńcze, a zatem również na charakter i formę ewentualnych enklaw przestrzennych. Do pewnego stopnia stanowić one mogą element obrazujący rzeczywistość, stanowiąc jej fizyczny wyraz. Ich zmiany obserwowane na planach miast i archiwalnych fotografiach stanowią opowieść o losach miasta i ludzi (Hall 1987). Warto też rozróżnić enklawę od getta, pojęć niejednokrotnie stosowanych zamiennie, częściowo za sprawą przeniknięcia tego drugiego do kultury popularnej. Odmienność owych pojęć zasadza się na kwestii woli ich mieszkańców: o ile współtworzenie enklawy jest dobrowolne (nawet pomimo ograniczonego, np. ekonomicznie, wyboru), o tyle getta nie zawsze (Haynes, Hutchison 2008).

Podział na "swoich" i "obcych" - pierwotnie insider i outsider (Relph 1976) - jest już mniej czytelny, stanowi natomiast dobry początek rozważań o przyczynach konfliktów przestrzennych (Chang 2000). Nie pozostaje bez znaczenia, jak zostaną określone granice tej odmienności, zawsze jednak wytworzą one grupy mające swoje własne cele wobec przestrzeni. Można spróbować oprzeć je na podziale pomiędzy rezydentami a osobami wizytującymi, w tym turystami. Już taki podział nie będzie jednak całkowicie jednoznaczny, tak jak nie można powiedzieć, że każdy turysta czuje się obcym, a każdy mieszkaniec utożsamia ze swoją dzielnicą. Jest tak po części dlatego, 
że obie te grupy znajdują się $w$ innej sytuacji: osoba odwiedzająca jest w danym miejscu najczęściej z własnej woli i chęci, rezydent natomiast może być zmuszony na przykład niekorzystną sytuacją ekonomiczną. Podobnie grupy etniczne, których rozmieszczenie $\mathrm{w}$ mieście niekoniecznie pokrywa się z występowaniem enklaw przestrzennych je reprezentujących, ukazują zacieranie się granic pomiędzy tym, co wewnątrz, a tym, co na zewnątrz. Przykładem może być wspólne korzystanie z przestrzeni enklawy podczas świąt religijnych bądź narodowościowych, co dowodzi, że funkcjonuje ona jako symboliczne centrum dla danej, nawet rozproszonej terytorialnie, kultury. Być może jednak ważniejszym podziałem $w$ duchu tej teorii jest podział na użytkowników przestrzeni z jednej strony i władze miasta oraz planistów $\mathrm{z}$ drugiej. Stoi za nim także asymetria $\mathrm{w}$ rozdysponowaniu środków przekształcania (Bockmeyer 2006). Dysponowanie władzą wobec przestrzeni, możność jej dopasowywania według własnej woli stanowić może narzędzie polityczne. Przykładem są tu procesy urbanistycznej odnowy (Tunbridge 1984) czy relokacja ludności (Yuen 2005). Za poszczególnymi grupami stoją inne cele, a będący wypadkową konfliktu i kompromisów rozwój urbanistyczny (Short 1996) stanowi ich świadectwo. Uproszczony model składa się $\mathrm{z}$ dwóch stron: skoncentrowanych $\mathrm{w}$ danym rejonie imigrantów, chcących utrzymać niezależność i kształt swojej dzielnicy, oraz z władz miejskich, w których subiektywnej ocenie istniejąca sytuacja może być problemem (Jałowiecki, Szczepański 2006).

\section{NARZĘDZIA PRZEKSZTAŁCANIA PRZESTRZENI}

Imigranci wykorzystują narzędzia, które można by określić mianem miękkiej architektury, w ramach ich ograniczonych prawem oraz zasobami możliwości. Zmiany mają raczej powierzchowny charakter, obejmując swoim zasięgiem pewien wycinek dostępnej im skali. Takie umiejscowienie i zaznaczenie swojej obecności za pomocą środków architektonicznych bliższe jest budowaniu lokalnego "centrum”, punktu na mapie poznawczej (Lynch 2011), niż tworzeniu granic - a zatem stanowiąc wartość dodaną, jest pozytywne. Wydaje się, że działania przestrzenne mieszkańców enklaw etnicznych mają na celu zaakcentowanie swojej obecności, w rozumieniu miejsca w przestrzeni (Tuan 1987), na względnie jednolitym terenie ośrodka miejskiego. Pewnym wyjątkiem mogłyby być pojawiające się w niektórych enklawach bramy, np. $w$ rejonie Little India $w$ Singapurze, Chinatown w Londynie, Vancouver czy Manili. Stanowią co prawda symbol granicy, jednak nie funkcjonują jako przegrody w systemie urbanistycznym. 


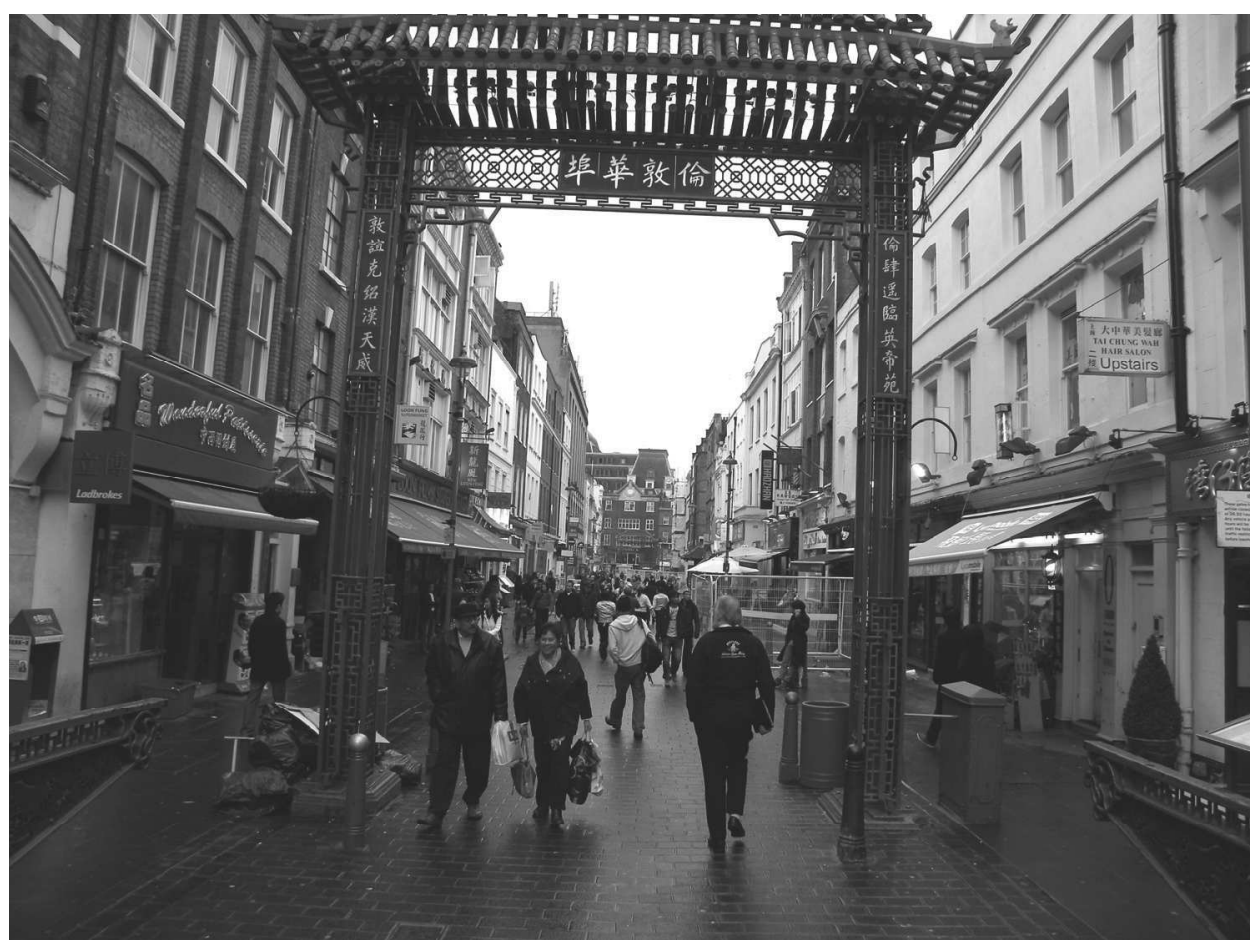

Brama Chinatown w Londynie (fot. J. Kubera)

W historii urbanistyki znaleźć można przykłady enklaw etnicznych, które stanowiły barierę przestrzenną zarówno w rozumieniu dosłownym fizycznym - jak i symbolicznym. Są wśród nich wyznaczane przez Niemców podczas II wojny światowej getta żydowskie w okupowanych miastach, np. w Warszawie, Łodzi czy Budapeszcie. Chociaż o ludności żydowskiej, nawet w tamtym okresie, trudno mówić jako o imigrantach - nie była ona bowiem w miastach nowa - to, stanowiąc wyraźnie odrębną grupę i często koncentrując się terytorialnie, pozwala zobrazować omawianą tematykę właśnie $\mathrm{w}$ aspekcie przestrzennym. Getta tworzone w trakcie II wojny światowej stanowią skrajne przykłady władzy nad przestrzenią miejską i zajmującymi ją ludźmi. W odróżnieniu od enklaw, stanowiących punkt bądź rejon na mapie miasta, były wyciętymi z jego tkanki białymi plamami, a także „etnicznym negatywem". Użycie środków architektonicznych do ich wyznaczenia leżało wyłącznie po stronie osób z zewnątrz - władzy. Elementem powtarzającym się jest zastosowanie muru - zarówno jako fizycznej bariery oddzielającej getto od reszty miasta o ograniczonych i ściśle określonych 
warunkach jej przekraczania (także ustalanych jednostronnie przez władzę), jak i symbolu. Jak wielką ma on moc, świadczy chociażby liczba pozostawionych i oznaczonych historycznych fragmentów murów dzielących ludzi, np. w Berlinie, Warszawie czy Budapeszcie (mur odbudowany w 2008 r., w dwa lata po jego rozebraniu). Jakkolwiek getta, zwłaszcza żydowskie, kojarzone są najczęściej z okresem II wojny światowej i Holocaustem, mają o wiele dłuższą historię. Już w nowożytności niektórym społecznościom wyznaczano konkretny teren do osiedlenia się, czasem także ograniczając prawa. Było tak zarówno w przypadku getta, powszechnie określanego jako pierwsze, założonego w 1516 r. w Wenecji (Haynes, Hutchison 2008), jak i krakowskiego Kazimierza, do którego Żydów zaczęto przesiedlać już pod koniec XV wieku (Jałowiecki, Szczepański 2006). Zabiegi takie były tym czytelniejsze przestrzennie - a zarazem symbolicznie - jeśli były wspomagane przez fizyczne ukształtowanie terenu. Miasto Kazimierz znajdowało się pomiędzy odnogą a głównym korytem Wisły, którą to sytuację można potraktować jako wydzielenie przestrzenne - a zatem granicę, poza którą zostali wysiedleni jego mieszkańcy. Teren getta był także oddzielony parkanem i murem. W przypadku Ghetto Nuovo w Wenecji - zalążka getta weneckiego - była to wyspa, połączona z resztą miasta mostami, których przekraczanie przez Żydów było obwarowane ścisłymi regułami (Haynes, Hutchison 2008). Powstanie, ewolucja i charakter urbanistyczny gett żydowskich stanowi osobny, interesujący problem choćby z tego powodu, że sama społeczność żydowska, zgrupowana w hermetyczne środowiska, podobnie jak inne mniejszości etniczne, często nie dążyła do asymilacji ze względu na odmienność kulturową.

\section{ZAZNACZANIE SWOJEJ ODRĘBNOŚCI W MIEŚCIE}

Inaczej na mapie miast odciskają się enklawy społeczności cechujących się mniejszym dążeniem do separacji. Zaznaczanie bowiem swojej odrębności wobec miasta, które stanowi tło, odbywa się przy większym wykorzystaniu środków architektonicznych niż granic oczytanych w skali urbanistycznej. Powszechne dla enklaw etnicznych jest wykorzystanie rodzimego języka na szyldach, jak ma to miejsce na przykład w rejonie tzw. Polish Triangle $\mathrm{w}$ Chicago, znakach, tablicach pamiątkowych i w nazwach ulic, wraz z nagromadzeniem lokali oferujących tradycyjne jedzenie, które już samo nie jest kulturowo neutralne (Martini, Chee 2001). Działanie takie ma kilka efektów. Z jednej strony, stanowi informację dla pozostałych członków grupy posługujących się wyłącznie tymże językiem lub też szukających 
rodzimych towarów, z drugiej, jest elementem przyciągającym turystów stąd występuje nawet $\mathrm{w}$ najbardziej skomercjalizowanych i podporządkowanych tkance miejskiej enklawach etnicznych - gdyż buduje tzw. klimat miejsca. Wreszcie jest także jednym ze sposobów fizycznego osadzenia tejże enklawy na mapie miasta. Umieszczone $\mathrm{w}$ dość sporym zagęszczeniu szyldy i znaki w języku ojczystym danej mniejszości stanowią bowiem w odbiorze miasta rodzaj punktu charakterystycznego - bądź rejonu w przypadku większej przestrzeni (Lynch 2011). Podobne zadanie wypełniają kolejne elementy odwołujące się estetyką do pochodzenia danej grupy, w tym tzw. mała architektura, czyli np. stylizowane latarnie, ławki, murki. W przypadku większych grup, a także przy sprzyjających warunkach, zaznaczenie swojego terytorium jest silniejsze (Bańka, 1999). W skali architektonicznej obserwujemy wtedy zwiększone występowanie obiektów architektury wernakularnej, budynków stylizowanych, czy też świątyń, jak np. Sri Veeramakaliamman na terenie Little India w Singapurze czy kościół św. Stanisława Kostki w Chicago. Co ciekawe, mogą to być zarówno budynki stawiane od podstaw, których nagromadzenie pogłębia efekt rejonu etnicznej enklawy, jak i wtórne - powstałe jako przekształcenie architektury zastanej. $\mathrm{Z}$ ich metamorfozy, zwłaszcza jeśli dotyczy to odległych od siebie kultur, powstać może niespotykane nigdzie indziej połączenie, które będzie lokalnym „stylem architektonicznym" enklawy.

Modyfikowanie istniejącej zabudowy jest zjawiskiem pośród enklaw częstym, jako że spora część emigracji zewnętrznych grup etnicznych do miast odbywała się na etapie, kiedy tkanka urbanistyczna ich przestrzeni centralnych już istniała. Pewnego rodzaju wyjątkiem spośród nich jest przykład dzielnicy chińskiej w San Francisco, która w 1906 r. po trzęsieniu ziemi i będących jego następstwem pożarach została wraz ze znaczną częścią miasta zniszczona i odbudowana od podstaw.

Jedne z najwyraźniejszych przykładów enklaw, budujących wrażenie ciągłości trwania, znaleźć można w Singapurze. To założone $\mathrm{w}$ pierwszej połowie XIX wieku przez Brytyjczyków miasto od samego początku było mieszanką kultur i nacji. Znalazło to swój wyraz już w pierwszym powstałym dla niego opracowaniu urbanistycznym, tzw. planie Jacksona (Dale 1999). Wytyczono w nim osobne rejony dla poszczególnych grup etnicznych Chińczyków, Hindusów, Brytyjczyków (tzw. European Town), Arabów i Malajów. W trakcie rozwoju miasta część dzielnic przesunięto, a ich przestrzeń została wchłonięta $w$ tkankę urbanistyczną. Ten los jednak oszczędził Chinatown, które znajdując się w tym samym miejscu od czasu lokacji, stanowi jeden z najlepszych przykładów enklaw etnicznych. Jej rdzeń - dzielnica ta bowiem rozrosła się i składa obecnie z kilku obrębów - odcina się od 
reszty zabudowy charakterem obiektów w stopniu, który nie pozostaje bez znaczenia w skali urbanistycznej. Chinatown jest obok Little India, drugiej znaczącej enklawy etnicznej Singapuru, jedną z niewielu czytelnych na mapie miasta dzielnic. Inaczej wygląda ich znaczenie w siatce komunikacyjnej metropolii. System transportowy całkowicie wchłonął obie te dzielnice, a także nowsze tereny Chinatown. Zdają się one zatem funkcjonować wewnątrz nowoczesnego miasta "na pewnych warunkach”, co zmienia ich status enklawy. Kolejnym minusem jest ich wątpliwa autentyczność. Dzielnice te, pomimo swojej tradycji i skali, nie oparły się bowiem komercjalizacji. Polityka urbanistycznej odnowy miasta przydała im cech skansenu lub parku tematycznego. Część terenów została objęta specjalnym nadzorem, fasady budynków odnowiono z myślą o turystach, co podniosło jakość estetyczną i walor tej przestrzeni jako atrakcji turystycznej, jednak kosztem ich oryginalności. Enklawy stały się przestrzeniami reprezentacyjnymi, a ich metamorfoza nie odbyła się bez skutków dla zmiany ich wartości $\mathrm{w}$ ocenie władz. Nastąpiła ona wraz z komercjalizacją, gdy to, co widziane jako inne, a być może i gorsze, przeobraziło się w przyciągającą ciekawostkę, dodającą miastu kolorytu. Utraciły więc swój pierwotny charakter, zmieniając niejako swoją orientację z wewnątrz na zewnątrz. Ukierunkowanie na turystów i na kulturę konsumpcji stało się cechą Little India w Singapurze, dostrzeganą także przez samych odwiedzających (Chang 2000).

Zadać by zatem należało pytanie, czy są to jeszcze enklawy etniczne. Czy może zostały z nich już tylko, podporządkowane polityce władz miejskich i planistów, a służące głównie przemysłowi turystycznemu, skanseny-parki tematyczne? Pytanie to, jak się wydaje, dotyczy szczególnie dzielnicy chińskiej w Singapurze, o której początkach decydowały warunki demograficzne, a konkretnie fakt, że ludność pochodzenia chińskiego stanowiła na tle reszty mniejszość, co uległo zdecydowanej zmianie. Obecnie Chińczycy są w Singapurze większością - w 2011 r. stanowili 74,1\% populacji (Population Trends 2011).

\section{4. ŚRODKI ARCHITEKTONICZNE W RĘKACH PLANISTÓW I WŁADZY}

Osobami kształtującymi „z zewnątrz” przestrzeń enklaw w miastach są planiści, mający władzę i narzędzia do jej egzekwowania. Mają oni także inne cele i zamierzenia wobec enklaw etnicznych, które, jak pisze Relph (1976), oparte są na logice, racjonalności i skuteczności. Trudno jednak stwierdzić, że działania władz całkowicie i zawsze pozbawione są emocji 
i politycznego wymiaru - już sam przykład niektórych gett temu przeczy. Możliwości, jakie mają osoby odgórnie kształtujące przestrzeń, dość dobrze obrazują przykłady $\mathrm{z}$ historii. $\mathrm{Z}$ jednej strony może to być zburzenie całego kwartału, jak miało to miejsce w St. Louis w Stanach Zjednoczonych, w miejscu, w którym powstało później znane osiedle Pruitt-Igoe (Bell i in. 2004). Kolejnym przykładem może być próba nakazania odbudowy enklawy w innym miejscu, jak miało to miejsce w San Francisco po katastrofie z 1906 r. (Choy 2012). Ustalana przez władze relokacja ludności występuje też pod innymi szyldami. Można by do niej zaliczyć politykę mieszkaniową Singapuru w latach sześćdziesiątych i siedemdziesiątych ubiegłego wieku, która swoim zasięgiem objęła też istniejące na terenie miasta enklawy etniczne (Yuen 2005), wspomniane osadzanie społeczności w gettach, a także ogólne akty prawne, jak choćby obowiązujący w Stanach Zjednoczonych w latach 1882-1943 Chinese Exclusion Act (Gyory 1998). Nieodległym przykładem jest też rewitalizacja i idąca za tym gentryfikacja (Stavrides 2010).

\section{POZAETNICZNE PODSTAWY PODZIAEU}

Interesujące z punktu badawczego, dla rozpoznania wzorców urbanistycznych enklaw na terenie miast, jest też ukazanie tych opartych na pozaetnicznej podstawie. Okazuje się bowiem, że korzystają one z podobnych rozwiązań. Opierając się zatem na wspólnym mianowniku w postaci przekształceń struktury z wyróżnieniem grup na „wewnętrzne” i „zewnętrzne” na podstawie dowolnych kryteriów - otrzymujemy pewnego rodzaju analogię. Spośród nieomawianych tutaj szerzej przykładów takie grupy czy enklawy mogą stanowić tereny należące do władzy politycznej, wojska, struktur religijnych bądź zamknięte tereny wystawowe, np. Międzynarodowe Targi Poznańskie. Można również zaklasyfikować do nich ogrodzone tereny mieszkalne, tzw. gated communities, dla których czynnikiem wyróżniającym są finanse, ale także podziały na tle rasowym, np. północne dzielnice Johannesburga (Dirsuweit, Wafer 2006). Specyficznym przypadkiem enklawy jest Watykan, choć $\mathrm{w}$ tym przypadku granice podkreślają odrębność państwową. Warto też wspomnieć o samozwańczej enklawie kulturowej w Kopenhadze - Christianii. Przytoczone przykłady mają ponadto charakterystyczne dla niektórych typów historycznych enklaw etnicznych ściśle ustalone reguły przekraczania granic. Występują w różnym natężeniu, mogą mieć inną formę, zależnie od charakteru danej społeczności i tego, co czyni ją odmienną. Różny stosunek do samego faktu podziału będzie to dodatkowo podkreślał. Część z podziałów może być powszechnie akceptowana z obu 
stron - i będzie tak najprawdopodobniej w przypadku wydzielenia terenów wojskowych czy obszarów zajmowanych przez władzę. Znajdą się też i takie, których przynajmniej część z bezpośrednio związanych z nimi osób nie oceni pozytywnie. Wydaje się, że choćby podziały zawierające $\mathrm{w}$ sobie element wartościowania mogą do takich właśnie należeć.

\section{POLSKA}

Na polskim gruncie ciężko mówić o tworzeniu się enklaw etnicznych mających swoje przestrzenne odbicie $\mathrm{w}$ strukturze urbanistycznej miast $\mathrm{w}$ podobnym stopniu jak $\mathrm{w}$ przytoczonych przykładach. Jednym $\mathrm{z}$ głównych powodów takiego stanu rzeczy jest stosunkowo niewielka liczba imigrantów na terenie kraju - według danych Urzędu ds. Cudzoziemców jest to zaledwie 0,2\% (Grzymała-Kazłowska, Piekut 2007). Jak piszą autorki badające wzorce osiedleńcze ludności ukraińskiej i wietnamskiej w Polsce, jedynie ta druga zdradza zalążki skupiania się w przestrzeni, niemniej jest to zjawisko o bardzo niewielkiej skali, brak też dowodów na stały charakter koncentracji, niebędący wynikiem sezonowych zmian na rynku pracy. Specyficznym rodzajem enklaw, obecnych także na terytorium Polski, są formowane przez ludność romską tabory. Stanowią raczej obozowiska przyległe do miast i wsi niż stałe osiedla wewnątrz nich, co nasuwa pytanie, czy podlegają ocenie za pomocą tych samych kryteriów co omówione wcześniej przykłady. Współcześnie zjawisko cygańskich taborów jest w Polsce śladowe, a stało się tak za sprawą działań ze strony władz PRL, które znacznie ograniczyły ich liczbę (Krzyżanowski, Pytlak, Bończuk 2002).

\section{ZAKOŃCZENIE}

Władza ma wiele możliwości działań twardych, w tym bezpośredniej ingerencji w strukturę urbanistyczną miasta, jego architekturę oraz rozmieszczenie jego mieszkańców. Można do nich zaliczyć tworzenie stref o specjalnych warunkach prawnych dotyczących architektury, opróżnianie konkretnej dzielnicy z mieszkańców i przemieszczanie ich $\mathrm{w}$ ramach miasta bądź wyznaczanie im lokalizacji poza nim. Będą też nimi szeroko rozumiane programy urbanistycznej odnowy i gentryfikacja, ale także masowe wyburzenia czy blokowanie możliwości budowy. Również podporządkowywanie dzielnic racjonalnej, regularnej siatce komunikacyjnej jest zabiegiem wpływającym na poziom odrębności enklaw. Z kolei ich użytkownicy, chcąc 
zaznaczyć swoją obecność, stosują różne techniki, mające jednak w dużej mierze charakter powierzchowny i estetyczny; można by powiedzieć, że dopasowują architekturę do swoich wymagań, wpływając na jej warstwę zewnętrzną. Wśród owych technik znaleźć można szerokie wykorzystanie swoiście rozumianej „szaty informacyjnej” miasta (Wallis 1979), a więc nagromadzenie szyldów, nazw ulic, elementów małej architektury oraz detalu architektonicznego w bezpośrednim nawiązaniu do swojej kultury i etniczności, zwłaszcza z wykorzystaniem rodzimego języka. $\mathrm{W}$ miarę posiadanych możliwości zmieniają również architekturę zajmowanego przez siebie terenu, bądź to stawiając nowe budynki, bądź przerabiając istniejące. Nie bez zmiany pozostają także funkcje obiektów - pojawiają się świątynie, restauracje $\mathrm{z}$ tradycyjnym jedzeniem czy sklepy $\mathrm{z}$ oryginalnymi wyrobami danej społeczności. Wokół swoich terenów stawiają też czasem symbole granic. Poszczególne przytoczone powyżej przypadki, a prawdopodobnie i pozostałe, o których nie było mowy, są inne, a ich forma wynika $z$ historii miejsca oraz ze specyfiki i siły kultur, których koegzystencji dotyczą. Ich współczesna kondycja i kształt też nie pozostają bez znaczenia - stanowią obraz sytuacji, którą można interpretować, czytając język architektury. Przechylające się na korzyść miast dane ilościowe w statystykach demograficznych oraz kontynuacja migracji do dużych ośrodków miejskich, np. w zachodniej Europie, sugerują, że omówione tu zjawisko będzie się rozwijać, być może wytwarzając nowe, na miarę naszych czasów, wzorce przestrzenne, które stanowić będą $w$ przyszłości interesujący materiał badawczy. $\mathrm{Z}$ jednej strony całkowita segregacja etniczna $\mathrm{w}$ miastach, wraz ze ściśle przestrzeganymi warunkami przekraczania granic, prowadzić może do społecznej izolacji grup, a nawet do ich dyskryminacji. Dzieli także przestrzeń urbanistyczną, rozbijając jej spójność i tworząc na jego mapie niedostępne białe plamy. Z drugiej jednak, jak pisał Alexander (Alexander i in. 2008: 43), mozaika podkultur o czytelnie określonych granicach wspomaga swobodę wyboru stylu życia oraz integruje sąsiedztwa, natomiast "homogeniczny i jednolity charakter współczesnych miast zabija różnorodność stylów życia i hamuje rozwój indywidualności".

\section{BIBLIOGRAFIA}

Alexander C., Ishikawa S., Silverstein M., Jacobson M., Fiksdahl-King I., Angel S. (2008), Język wzorców: miasta, budynki, konstrukcje, GWP, Gdańsk.

Bańka A. (1999), Architektura psychologicznej przestrzeni życia: behawioralne podstawy projektowania, Gemini-Print, Poznań. 
Bell P.A., Greene Th.C., Fisher D., Baum A. (2008), Psychologia środowiskowa, GWP, Gdańsk.

Bockmeyer J. (2006), Social Cities and Social Inclusion: Assessing the Role of Turkish Residents in Building the New Berlin, "German Politics \& Society" no. 24(4).

Chang T.C. (2000), Singapore's Little India: A tourist attraction as a contested landscape, „Urban Studies” no. 37(2).

Choy P.P. (2012), San Francisco Chinatown: A Guide to Its History and Architecture, City Lights, San Francisco.

Dale O.J. (1999), Urban Planning in Singapore, Oxford University Press, New York.

Dirsuweit T., Wafer A. (2006), Scale, Governance and the Maintenance of Privileged Control: The Case of Road Closures in Johannesburg's Northern Suburbs, „Urban Forum” vol. 17, no. 4.

Grzymała-Kazłowska A., Piekut A. (2007), „Mała Ukraina” czy polskie Viettown? Społeczno-przestrzenne wzory zamieszkiwania imigrantów w metropolii warszawskiej, „Studia Regionalne i Lokalne" nr 4(30).

Gyory A. (1998), Closing the Gate: Race, Politics, and the Chinese Exclusion Act, The University of North Carolina Press, Chapel Hill.

Hall E.T. (1976), Ukryty wymiar, PIW, Warszawa.

Hall E.T. (1987), Bezgłośny język, PIW, Warszawa.

Haynes B., Hutchison R. (2008), The Ghetto: Origins, History, Discourse, „City \& Community" no. 7(4).

Jagielski A. (1974), Geografia ludności, PWN, Warszawa.

Jałowiecki B., Szczepański M.S. (2006), Miasto i przestrzeń w perspektywie socjologicznej, Wydawnictwo Naukowe Scholar, Warszawa.

Krzyżanowski P., Pytlak G., Bończuk L. (2002), Cyganie: mity $i$ fakty, Stowarzyszenie Twórców i Przyjaciół Kultury Cygańskiej im. Bronisławy Wajs-Papuszy, Gorzów Wielkopolski.

Lynch K. (2011), Obraz miasta, Archiwolta, Kraków.

Martini F., Chee W.T. (2001), Restaurants in Little India. Singapore: A study of Spatial Organization and Pragmatic Cultural Change, "Sojourn” no. 16(1).

Population Trends (2011), Singapore Department of Statistics, Social Statistics Section.

Relph E. (1976), Place and Placelessness, Pion, London.

Short J. (1996), The Urban Order: An Introduction to Cities, Culture and Power, Blackwell, Oxford.

Stavrides S. (2010), Towards the City of Thresholds, http:/ / www.professionaldreamers.net/ _prowp/wp-content/uploads/978-88-904295-3-8.pdf [dostęp: 21.09.2013].

Tuan Y.F. (1987), Przestrzeń i miejsce, PIW, Warszawa.

Tunbridge J.E. (1984), Whose Heritage to Conserve? Cross-cultural Reflections on Political Dominance and Urban Heritage Conservation, „The Canadian Geographer/Le Géographe canadien" no. 28(2).

Wallis A. (1979), Informacja i gwar: o miejskim centrum, PIW, Warszawa.

Yuen B. (2005), Squatters No More: Singapore Social Housing, World Bank Third Urban Research Symposium: Land Development, Urban Policy and Poverty Reduction, April, Brasilia, Brazil. 